\title{
Fostering translingual dispositions against Unequal Englishes
}

\begin{abstract}
Despite solid work on the structural, sociolinguistic and political legitimacy of the Englishes of the world, the fact remains that some Englishes are more privileged than others. Thus, the circulation of different Englishes in the classroom demands a call to dismantle the symbolic and material infrastructures of unequal Englishes. This paper explores the complex dynamics of fostering translingual dispositions against unequal Englishes in English language classrooms. It argues that dispositions which embrace the plurality of English must also include the imperative to act on and work against ideologies and practices which unequally value and stratify different Englishes in the classroom. Fostering translingual dispositions does not always result in unmasking or overturning ideologies, practices and structures of unequal Englishes, but it surfaces conflicted conditions and ideologies which may progressively lead to addressing linguistic inequalities in the classroom, making learning of English more just and compensatory.
\end{abstract}

Keywords: Unequal Englishes, World Englishes, English-medium Classrooms, Linguistic Inequality, Translingualism

\section{Introduction}

Translingual dispositions, according to Lee and Jenks (2016), refer mainly to speakers' general openness to linguistic diversity, a positive and embracive attitude towards differences and plurality in the way people use language. In the context of English composition pedagogy, fostering translingual dispositions is important in helping students deal with diverse communicative contexts which demand sensitivity to the pluralized and dynamic nature of the English language. Translingual dispositions in this sense help students in "assuming and anticipating different Englishes" (340), not to guard against them but to open up to them and accommodate them in one's communicative and ideological repertoire in composition. Therefore, in this sense, dispositions which encourage openness towards differences in culture, language, and belief system, are intrinsic to developing constructive and effective translingual practices (Lee and Canagarajah 2019). 
This paper explores how to foster translingual dispositions against unequal Englishes in English language classrooms. Different Englishes are unequal Englishes, thus dispositions which embrace the plurality of English must also include the imperative to act on and work against ideologies and practices which unequally value and stratify the different Englishes which circulate in English language classrooms. Despite solid work on the structural, sociolinguistic and political legitimacy of the Englishes of the world, the fact remains that some Englishes are more privileged than others. A language, according to Bourdieu (1997), "is worth what those who speak it are worth" (652), thus the world in which languages operate is not an unbridled world where these languages move on their own apart from their speakers. Rather, languages circulate within the structure of a linguistic market, defined and configured by dominant social institutions, with rules of use and specific configurations of social relations between users of languages. Consequently, languages take on different values based on the ideological, social and economic logics of the linguistic market, with language users engaged in linguistic exchanges based on their appraisal of differentiated values accruing to different languages. By extension, the use of Englishes is always located within specific linguistic markets (Park 2011), thus the market values of these Englishes are also shaped and largely controlled by social and elite institutions, necessarily leading to some Englishes more privileged than others. It is in these linguistic markets where certain ideologies and practices - such as native-speakerism and monolingualism - are mobilized by these institutions and people and groups representing them. Thus, within the structure of a linguistic market of Englishes, certain speakers, students or socioeconomically disadvantaged speakers for example, are disenfranchised because the variety or varieties they speak are of low value in the market. If schools operate within the logics of this market, they then marginalize students' linguistic and cultural experiences and identities which, in turn, impact the students' own performance in language learning in class (Goddard et al. 2013). 
Thus, the circulation of different Englishes in the classroom demands a call to dismantle the infrastructures of unequal Englishes. Translingual dispositions in this sense include sensitivity not only to linguistic difference, multiple identity formations, and different deployments of semiotic resources for meaning-making; in fact, not only sensitivity to how different languages, language varieties, identities and semiotic communicative repertoires are unequally valued and distributed in the classroom, but also the imperative to act on linguistic inequalities constructed and sustained through the use, the teaching and learning of English. This is how this paper frames the idea of doing translingual dispositions (Lee and Jenks 2016) which is akin to Pennycook's (2019) call for translingual activism which "aims to destabilize the normative meanings of society" (180) such as those associated with monolingualist and native-speakerist views of teaching and learning, in order to enact the "ethical imperative for students to be able to speak otherwise (180, italics as original; see also Pennycook 2006). In fact, both students and teachers should be able to speak otherwise in the classroom.

This paper examines the complex ways one teacher in an English language writing classroom in Singapore aimed to foster translingual dispositions among her. Specifically, it looks at how the teacher deploys strategies in subtle ways to address unequal Englishes to make the teaching and learning of English less harmful to students whose linguistic repertoires are undervalued - or in fact, suppressed - by the educational and political establishment. Although this paper draws on the experiences and beliefs of one teacher, as will be shown later in the paper such experiences and beliefs are juxtaposed against those of other teachers whose classroom life trajectories have been examined in other research projects as well. Moreover, the case of this teacher is put forward as one example of how fostering translingual dispositions is not a straightforward undertaking: it can happen even if one continues to be subjected to standard language and monolingualist ideologies, as well as 
work under conditions of tight control from the state and state institutions such as education. In other words, this paper examines how the teacher wrestles with unequal Englishes in the classroom, aiming towards openness to English linguistic diversity but also confronting dominant ideologies of the school along the way. This is where the idea of doing translingual dispositions is relevant (Lee and Jenks 2016) because what we see is not simply a teacher's growing accumulation of dispositions which help her prepare for and deal with linguistic diversity in the classroom, but rather we see a teacher's agentive (or active) deployment of embracive dispositions within conditions of unfreedom. Such deployment does not always result in unmasking or overturning ideologies, practices and structures of unequal Englishes, but it surfaces conflicted conditions and ideologies which nevertheless showcase the teacher's progressive work towards addressing unequal Englishes in the classroom in order to make the learning of English more just and compensatory.

\section{Translingual dispositions and World Englishes}

For at least four decades now, the field of World Englishes has opened up, led and championed debates on the pluralization and localization of English (Kachru 1986; 1996; Smith 1987; Platt et al. 1984; see Saraceni 2015, for a comprehensive critical analysis of the field). A key argument of the field pertains to how the spread of the English language through the mechanisms and infrastructures of colonialism and globalization has been culturally, ideologically and politically mediated by its users and their respective languages and cultures (Kachru 1986; Bhatt 2001). Writing about English in India but in a way that is also relevant to the changing nature of English in other parts of the world, Chakravarti (2008) contends that there is no need to erase or forget the colonial history of English just so it can be justified 
as a globalizing and/or globalized language: "[i]t is precisely this history which has made it an Indian language" (51, italics as original).

To put it in another way, the globalization of English has resulted in its localization in contexts where it is used. Thus, changes to English are systemic or patterned changes, as well as are cultural appropriations of the language reflective and constitutive of speakers' identities, worldviews and values. Consequently, changes cannot be viewed as inferior to privileged ('native speaker') norms and standards, and must be considered acceptable, appropriate and even correct. If such changes are devalued or ignored, one is also guilty of suppressing and undermining the life experiences, identities and worldviews of the speakers through whom such changes have occurred.

World Englishes has offered linguistic (Smith 1987; Platt et al. 1984), sociolinguistic (Kachru 1986; Bolton 2019), and political/ideological frameworks (Bhatt 2001; Mesthrie 2019) through which scholars and educators justify the need to recognise and legitimize a wider range of norms and practices in the teaching and learning of English. They argue that such recognition and legitimization are necessary to help many students and learners (silenced or disadvantaged because their linguistic and cultural repertoires do not align with school-privileged language practices and cultural identities), do better in school, for example by drawing on their own localized uses of English as resources for teaching and learning, and/or allowing them to use their 'non-standard' English(es) to give them voice in knowledge-making, story-telling and identity-forming activities and practices in the classroom.

Expectedly, the role of World Englishes in English language pedagogy has been and continues to be controversial and contested (Matsuda 2003; Velasco 2019), even if sound arguments have been put forward to question the many 'sacred cows' of English language teaching such as the superiority of 'native speaker' norms and standards and the 
appropriateness of Western-drawn language teaching methods (Kachru 1988; Matsuda 2003). It is because standard language ideologies and native-speakerism endure in the practices and beliefs of teachers, students, administrators, and parents (Velasco 2019), sometimes discursively hidden behind pragmatic justifications for the use of 'standard' English in the classroom (Sadeghpour and Sharifian 2019). Standard language ideologies are beliefs about the desirability and legitimacy of a particular language or language variety or what Bourdieu (1997) refers to as 'authorized language', while native-speakerism refers to a network of beliefs about the superiority of the variety of English associated with 'native-speakers' (Holliday 2006). These colonially-induced ideologies and practices continue to shape the English language today and are sustained by infrastructures of teaching and learning such as global assessment and textbook industries, development aid projects and the internationalization of English-medium education. Consequently, WE proponents and supporters persistently explore ways to confront and/or resist such ideologies and practices in the classroom, involving "multiple levels of initiatives, from the classroom to society at large" (Matsuda 2003, 723). These initiatives include exposing students to "various Englishes in the classroom" (723), evaluating them "on their communicative effectiveness rather than solely on grammatical correctness based on the American or British norm" (723), using materials which "can include more main characters from the outer and expanding circles" and give them larger roles than what they currently take on (724), introduce WE in teacher education programmes (725), use school occasions such as parents-teachers meetings and open campus programmes to expose parents and their children to sociolinguistic realities in which the use of English occurs, and use the mass media to disseminate sociolinguistic ideas (726). Different Englishes are sociolinguistic realities and incorporating them into school curricular will open up the English language classroom to the reality of linguistic diversity. 
Broadly speaking, translingualism departs from World Englishes in terms of the way speakers' communicative repertoires are conceptualized. Shifts between Englishes assumes the existence of boundaries between named codes such as 'Englishes' (see Matsuda's examples in the preceding paragraph), but with translingualism named languages and language varieties are supposed to have no psycholinguistic validity because speakers holistically draw on a whole unitary range of linguistic and semiotic resources for communicative meaning-making. It is the entirety of such resources which constitutes the communicative idiolect of a person ( $\mathrm{Li} 2016,4)$ which means that one cannot break down the idiolect into different and smaller parts because there are no parts or boundaries to start with. The communicative resources act as one unified code - "a unitary linguistic system" (García and Otheguy 2019, 9) -- from which meanings and functions emerge in interaction (for a critique of this position, see MacSwan 2019).

It is, of course, ironic that in the process of evidencing the wholeness of a person's communicative repertoire, named languages and language varieties are drawn upon to prove that they do not exist in practice. For example, "one needs to know Chinese in order to fully understand the meanings of the phrases" (Li 2016, 14), or "The teacher does not speak any of these [named] languages, although she does speak Swedish and English" (García and Otheguy 2019,13$)$. Such is starkly the case in translingual pedagogy where descriptions of classroom translingual discursive practices include teachers' and students' abilities to shift between codes, for example when a teacher begins the interaction with one code (or language or language variety) and the student(s) respond(s) using another (e.g., García and Lin 2017; Vaish and Subhan 2015), or when pupils ‘switch' between languages in translanguaging creative writing activities (Barbour and Quinn 2020). Recently, there has been increasing recognition of translingual practice as a phenomenon that goes beyond language and encompasses the entirety of speakers' meaning-making communicative experience (Li 2018; 
García and Otheguy 2019). This means that the translingual experience is the communication experience of every human speaker, including that of the so-called 'monolingual' speakers because not only is their use of 'one' language inflected with multiple accents and identities but they also simultaneously draw on other non-linguistic semiotic resources and different modalities of communication (e.g., spoken, written, visual/non-verbal, online; technologically-mediated) to produce meaning and cement social relationships through communication.

Consequently, what is required of all speakers in today's globalized, interconnected and - some scholars argue - superdiverse world (Vertovec 2007; Arnaut et al. 2015), is the harnessing of translingual dispositions among all speakers for the successful operationalization of the translingual experience in actual communicative interactions. Human communication is, after all, intercultural communication (Byram 1997) where what is needed are not simply the use of the 'right' codes but also the deployment of appropriate practices, rhetorical moves, attitudes, beliefs, and ideologies which embrace differing communicative repertoires between speakers in social interaction. Doing translingual dispositions, in other words, is engaging in translingual activism (Pennycook 2006; 2019), developing critically aware speakers who do not simply perform translingual practice as a matter of course but most especially use the translingual experience to work towards both building harmonious rapport and mutual respect between speakers, as well as correcting possibly asymmetrical social relations in the interaction due to use of differently and unequally valued communicative repertoires. Translingualism viewed this way is one way to "bring visibility to minority communities, build student confidence and pride in their cultural heritage, and facilitate an environment of inclusivity, sensitivity and open-mindedness throughout the most formative stages of child development" (Barbour and Quinn 2020, 17). Translingual experience is constitutive of one's communication experience, but how one 
harnesses such experience to improve or alter interpersonal and social relations depends on how people $d o$ translingual dispositions.

Thus, doing translingual dispositions is what binds translingualism (Lee and Jenks, 2016) and WE (Canagarajah 2006; Matsuda 2002) together as both aim towards embracing and promoting linguistic diversity amidst a world of enduring ideologies and practices of linguistic essentialism, monolingualism and native-speakerism. Through the lens of WE, Canagarajah (2006) looks towards harnessing transnational relationships between speakers of different Englishes; Kubota (2001) seeks to promote shared responsibility in international communication by helping 'native-speaking' American students develop a positive attitude towards other(ed) non-native Englishes; Jarvis and Bokor (2011) see ethos transformation among the same group of students in the global context of technical communication. On the other hand, through the lens of translingualism, Lee (2014) describes positive changes in students' perceptions of themselves as language users in and outside of the classroom when codemeshing as a translingual strategy is introduced in composition pedagogy in the US to open up the curriculum to harness dispositions which embrace the plurality and multiculturality of English. Kimball (2015) shows how a translingual orientation helps students understand and work with language and literacy in more open and enlightened ways, and that such an orientation will enhance effective engagement of those who work in and for literacy community literacy projects. Both $W E$ and translingualism aim towards getting everyone to do translingual dispositions, although the call to act on linguistic inequalities engendered by our experience with plurality and difference is still not consistently and overtly supported.

\section{Fostering translingual dispositions against unequal Englishes}


In this section, I surface and examine some challenges and possibilities of doing translingual dispositions to work against unequal Englishes. These will be done through an examination of ideologies and practices of one teacher of English in Singapore. The sample data is drawn from a larger data set generated through a research project which sought to examine cross-cultural content and pedagogy in English language writing classrooms in selected secondary schools in Singapore.

The project, entitled 'Fostering Cross-cultural Communication and Understanding in the English Language Writing Class', sought to find out to what extent cross-cultural skills (endorsed by the education ministry as skills needed to produce globally-oriented Singaporeans) are promoted in English language classrooms in Singapore. Three secondary schools and two teachers from each of these schools were involved in the study. Two-week Secondary 2 lessons covering a particular topic within the schools' own-designed English language programme or curricula were observed (video and audio recorded), resulting in a total of 31.5 hours of teaching observed from all six teachers. In addition, follow up interviews with teachers immediately following every lesson observed were conducted, as well as four focus group discussions (FGDs) with all participating teachers conducted by all five members of the research team. A content analysis of textbooks and other relevant materials used (e.g., PowerPoint slides, worksheets and exercises) was also conducted to determine the potential of cross-cultural content in these teaching resources and whether or not the teachers exploited such content in actual teaching.

The extent of and motivation for the use of Singlish in the classroom was not one of the research project's objectives, but data emerging from the research clearly showed that the presence of Singlish in the classroom was an important element in teachers' and students' engagement with cross-cultural communication. Singlish or Colloquial Singapore English is a result of language contact between English-using Singaporeans who speak different 
languages as well such as Malay, Hokkien, Tamil, and other Chinese languages. It serves as the 'informal' lingua franca in Singapore but is frowned upon officially. While it exists in the classroom as well, it is not officially endorsed as a legitimate tool for teaching and learning. The topic and shape of this paper, in other words, were generated through the data and did not come as a pre-determined topic seeking to directly find out what teachers and students do to capitulate to or resist the presence of unequal Englishes in the classroom. In particular, teachers generally believe that Singlish is integral to promoting and developing cross-cultural awareness and skills, but they struggle with what to do with it because of strong standard language ideologies and tight state-imposed practices shaping the teaching of English in the country. Therefore, this paper does not represent the main objectives of the research project, and the data used proceed through theoretical frameworks which are different from what were used in the project. The sample data are presented to examine what one of the teacher participants has done to Singlish in the classroom and why she does what she does under conditions of institutional surveillance which prohibits the use of Singlish in teaching and learning English, and thus perpetuates Unequal Englishes in the classroom.

\section{Unequal Englishes}

Unequal Englishes as a concept refers essentially to the unequal world of Englishes which circulates within a community of multilingual speakers (e.g., Tupas 2015; Li 2015; Dovchin et al. 2016; Sabaté-Dalmau 2018). It is also a critical approach to understanding the politics of Englishes today, seeking not only to point to how different Englishes are unequally valued, but also to transform social relations between speakers who use different Englishes. Indeed, different Englishes are unequally valued which thus structure or shape social 
relationships between speakers, as well as determine or influence these speakers' life chances due to differentiated access to privileged English(es).

Unequal Englishes, however, is not merely a descriptive term which loosely refers to any form and practice of English linguistic inequality, but it also points to the coloniality of ideologies and practices which sustain such inequality. In other words, the conceptual strength of Unequal Englishes does not lie simply in how it alerts us to the unequal world of Englishes and speakers (because this is a point made many times over for many decades now), but in how it frames our understanding of injustices engendered by unequally valued ideologies and practices of Englishes along a historical trajectory which links the present with colonially-induced ideologies and political structures of the 'past'.

\section{Why Singapore?}

Singapore is a good context for examining the politics of Englishes because of its unique trajectory in language and educational policy-making. After formally asserting its political independence from the British colonial government in 1956, Singapore embarked on what many recognize as one of the most successful educational and economic transformations in the postcolonial era (Lee et al. 2008; Lim 2015). Official statistics show a historically stable ethnic composition among the state-determined 'CIMO' ethnic groups Chinese (74.3\%), Malay (13.4\%), Indian (9\%) and Others (3.2\%) (Data.gov.sg, 2018; see Bolton and $\mathrm{Ng} 2014$ ) - but these statistics actually hide a much more diverse multilingual and multicultural make-up as each of these official categories in fact "flattens and 'homogenises' ethnic, linguistic and religious differences within the category itself" (Chua 2009, 240). The country's bilingual policy has served as the cornerstone of the country's nation-building project (Lim 2015). The policy essentially refers to the privileging of English and three 
'mother tongues,' namely, (Mandarin) Chinese, Malay and Tamil in education, thus also making these four languages the official languages of the country. Although Singapore is somewhat unique for calling itself officially as a 'multicultural' nation (Chua 2009), it is nevertheless both reductive and hegemonic in relation to how it has privileged English as the primary medium of instruction, as well as how it has ignored or swept over all other indigenous languages. The bilingual policy, in other words, has served as an ideological and political platform through which multilingualism and multiculturalism could be 'managed' (Chua 2009), thus resulting in at least two major sociolinguistic transformations in Singapore society. First is the minoritization of other(ed) languages (Wee 2014b), including the destruction of erstwhile dominant Chinese 'dialects', and second is the displacement of indigenous languages by English as the most preferred or dominant home language, an "unforeseen and unintended consequence of official language policies" in the country (Bolton and Ng 2014, 311). Thus, from being an 'English-knowing' (Pakir 1991) multilingual country, Singapore has become an 'English-dominant' nation (Tupas 2011), still with persistent "tensions" because of the "disjunct between presiding policy and the evolving ecology" (Lim 2015, 263). In recent official statistics, English has replaced other languages as the main language of the home, prompting some scholars to begin conceptualizing English as one of the country's 'mother tongues' (Tan 2014), thus ironically going against the core aim of the bilingual policy which is to produce bilingually competent Singaporeans speakers who are equally competent in English and in any official 'mother tongue'. Thus, the bilingual policy, actively promoted by the government, has contributed to Singapore's "increasing linguistic homogeneity" (Bolton and $\mathrm{Ng} 2014,316$ ) along the trajectory of the continuing and still amplifying dominance of English, a legacy of colonialism. 
With the bilingual policy as crucially responsible for the country's economic transformation, making it one of the most globally competitive nations today, Singapore thus is a potent and rich context for examining the complex postcolonial politics of English language use today. The privileging of English can be seen clearly through the institutionalization of the language as the primary medium of instruction in all levels of education since 1987. Such privileging, centrally through education and state institutions, has resulted in its localization and indigenization. Singapore's deeply multilingual and localized use of English has produced Colloquial Singapore English or Singlish, with many Singaporeans claiming ownership over it (Wee 2018; 2014a; 2002), supposedly indicating that the country has veered away from the colonial vestiges of the English language. Yet, Singlish and, for that matter, its use have historically been disparaged even by official/state discourse on language and communication, precisely because colonially-induced standard language ideologies continue to embed official and public discourse, labelling the local use of language as corrupted and anathema to the nation's progress towards global competitiveness and quest for cosmopolitanism (Hiramoto 2019; Chua 2015; Wee 2014a; Kramer-Dahl 2003). Singlish has taken on derogatory undertones such that even today when state discourse has somewhat opened up to the identity-affirming role of the local variety of English (Hiramoto 2019), the use of it is by and large still considered a handicap (Chua 2015; Lim 2015). This is especially so in the context of education where the 'interference argument' (Wee 2014a; 2018) - Singlish is the reason why many students cannot master 'standard' English - remains rooted in classroom practice, policy-making, and teacher and student ideology (Tupas 2018; Fong et al. 2002). Consequently, training our focus on what Pennycook (2017) refers to as the "effects of unequal Englishes" (ix, italics as original), the dominant use of Singlish in the classroom is not only deemed detrimental to learning English but is also stripped of its 
potential to help facilitate the learning of English while sustaining its identity- and culturallyaffirming role in communication and learning. Research for at least two decades now has shown how the use of non-standard Englishes as a cultural and pedagogical resource in English language classrooms has resulted in improved academic performance among their users, as well as greater clarity of the users' understanding of who they are as learners and speakers of English (Wheeler 2006; Fong et al. 2002; Tupas 2018). The question now is how to foster translingual dispositions among teachers and students against colonially-induced English linguistic inequality but with the view that such an undertaking happens within conditions of unfreedom where teachers and students work amidst tight state-regulated mechanisms and ideologies of teaching and learning, i.e. "tightly governed by the MOE" (Tan and Dimmock 2014, 746) or the Ministry of Education, and "unwavering desire of Singapore leaders to exert control and influence over schools," resulting in the country being “an example par excellence of elite management" (PuroShotam 2011, 11, italics as original).

\section{Xue Yu's struggles with Unequal Englishes}

The case of Xue Yu (not real name), a teacher in a neighbourhood school (loosely speaking, a non-elite school), is used in this paper to show how fostering translingual dispositions may work, even if one's stand is not necessarily a clearly critical or transformative position against unequal Englishes. Although drawing only on one teacher's classroom practice, other research is referred to in order to expose unexplored acts of resistance against unequal Englishes not only under conditions of institutional and ideological surveillance, but also emerging from tensions experienced by teachers themselves who simultaneously subscribe to but also attempt to dismantle the privileging of Standard English. Xue Yu's struggles with unequal Englishes may be accounted for in three overlapping ways. 
First, while she puts forward the point that Singlish is a legitimate form of communication, she does not openly endorse its use in the classroom. In fact, when directly confronted by a question which seeks her opinion on whether or not a particular sample Singlish utterance can be used, she avoids answering the question. Second, she is conflicted ideologically regarding the status of Singlish in the classroom. On the one hand, she believes that Singlish has a place in the classroom because of its role in establishing interpersonal relations, she continues to subscribe to the idea that using it in the classroom is not a good idea. And third, despite these overlapping concerns and ideologies, Xue Yu nevertheless opens up spaces in the classroom where Singlish is discussed openly and positively, only that she does this in subtle or indirect ways.

Xue Yu avoids explicitly legitimizing use of Singlish. Typical of teachers in Singapore, Xue Yu works largely under conditions of restraint because teachers are expected to tow the line of the Ministry of Education in practically all aspects of teaching and learning, while such official line draws on ideologies and practices which are framed within conditions of neoliberalism and coloniality (Koh 2004). State discourses on language also circulate widely in society, thus making it difficult for teachers to openly endorse Singlish as a pedagogical resource (Wee 2014a), especially that the government has launched massive campaigns to discourage Singaporeans from speaking Singlish in the name of global competitiveness (Lim 2015; Wee 2014a; Kramer-Dahl 2003; Rubdy 2001). It has been made clear that speaking 'good' English is a national or moral duty (Kramer-Dahl 2003; Lim 2015) because teachers "are inevitably expected to be the role models of SSE [Singapore Standard English] so as to bring about a generation of intelligible Singaporeans" (Alsagoff and Kwek 2006, 2). Thus, for teachers like Xue Yu using Singlish as a resource for learning and teaching in the classroom cannot be openly embraced. In the following classroom excerpt, Xue Yu begins the lesson by introducing the topic of Singlish to the students. It is actually a small part of a 
longer stretch of an introductory spiel by Xue Yu on Singlish as this would then be followed by a discussion of an article on the same topic in order to teach expository writing. When confronted by a question by a student that would seemingly explicitly legitimize Singlish, Xue $\mathrm{Yu}$ avoids the question and moves on to talk about other things:

Xue Yu: ... have you ah ever used Singlish and then someone mentioned that 'I don't understand.

Student A: Yes...my friend.

Xue Yu: Ok your own friend, who said that?

Students: Nathan.

Xue Yu: Nathan said that, very interesting...anybody who says that? Who speaks Singlish then, anyone?

Students: Everyone

Xue Yu: But there are some people who are very comfortable with it. Amy?

Student B: She speaks perfect Singlish.

Xue Yu: Perfect Singlish!

Xue Yu: You ask her lah.

Xue Yu: That's interesting.

Student C: Can we say 'Can borrow me your pen'?

Xue Yu: That is a structure of Chinese isn't it? You say 'Borrow me your pen'...ah we did that already..right? Ah ok. Now we'll show some slides which I took when I was in China.

Immediately preceding this exchange, and in several occasions in the lesson and the follow up lesson in the next session, Xue Yu actually provides basic contrastive analysis of 
English and Chinese syntactic structures to prove the point that Singlish is a legitimate form of communication. However, in the excerpt above she avoids answering the student's pretty tricky question as this would place her in a situation where she could legitimize its use among students. For her (as will also be hopefully clearer below), Singlish is a legitimate language but she runs short of endorsing its use, especially in such a highly formal and ideologically tightly controlled environment. In her lessons throughout, Xue Yu espouses the belief that students must learn standard English. To put it in a more conceptual manner, while Xue Yu sees Singlish as legitimate on linguistic grounds but she believes that it does not have 'language legitimacy' (Reagan 2016) which refers essentially to the belief or assumption that "particular languages, or language varieties, are in some sense superior to others" (2).

Xue Yu acknowledges the role of Singlish in the classroom but is ideologically conflicted. In one of her post-lesson interviews in the course of our research, Xue Yu admits that she speaks Singlish in class, and it is here where we glean through her thinking and practice that she struggles with the presence of Singlish in the classroom even if she firmly believes there is use of it in teaching and learning. On the one hand, Xue Yu explains that she uses Singlish in order for students to feel close to her:

Xue Yu: ...in class I sometimes fall into you notice Singlish because I hope it's wrong but I think that's the only way sometimes to make them feel that they are near me that that oh I'm with her now

Interviewer: I agree

Xue Yu: because if I were to speak so formally all the time I notice that I'm away from them you know I'm standing on some pedestal and they are looking at me 
On the other hand, she also confesses to be feeling relieved every time her students alert her to her use of Singlish because at least they are aware of Singlish as a non-standard use of English.

Xue Yu: so sometimes I do that but, but most of them would say that's Singlish, to attract your attention

Interviewer: so they are able to point out

Xue Yu: ah! Sometimes some of them would say 'Cher that's Singlish you know. I say yeah

Interviewer: that's right

Xue Yu: and, and, and im glad they do that

Interviewer: yeah

Xue Yu: because at least they they realise that.

Xue Yu recognizes the power of Singlish to establish rapport and interpersonal relations in the classroom, but is somewhat reassured that her students are able to identify uses of it in the classroom, even if this means students admonishing her for using Singlish. Such a conflicted view of the role of Singlish in the classroom is a common view among teachers (Chua 2015; Farrell and Kun 2007; Kramer-Dahl 2003; Rubdy 2001), acknowledging some pedagogical use of Singlish without necessarily endorsing its use in explicit ways. This is also in line with the broader study of Vaish (2012) among English teachers in Singapore who, because of their formal training in immersion learning, claim that they do not allow the use of any other language, including Singlish, in their classroom, even if they acknowledge that there is indeed wisdom is allowing such use. This is what Vaish describes as an "overlap of beliefs" (65) among teachers who, because of practical experience, see the usefulness of drawing on indigenous language resources to teach English, yet overwhelmingly endorse the use of English only to teach the language. 
Хие Yu aims to dismantle the singular hold of Standard English in the classroom, but uses subtle strategies. Nevertheless, instead of backtracking completely and despite espousing the official and popular line that Singlish has no place in the classroom, Xue Yu persists in helping her students develop translingual dispositions, albeit in subtle ways. For example, in introducing the organizational structure of expository writing, she uses an anchor essay featuring arguments concerning the use of Standard English and Singlish. Through this deceptively simple strategy to introduce Singlish in class, not only does she open up a space in the classroom to discuss Singlish in more nuanced ways (other than simply reminding students that Singlish is bad and cannot be tolerated especially in writing), it also gives her an opportunity to inform students of sociolinguistic insights about Singlish (see earlier studies which deploy similar strategies in the classroom and in teacher education, [Godley et al. 2006]). For example, she introduces the notion of 'codeswitching' to students, explaining to them that Singlish as informal language can be tapped into in a conversation if needed: "I want them to know at this level that you can use different language at different time and that's called code-switching". Thus, in discussing a particular specific paragraph in the essay, she clarifies the notion of codeswitching with the students:

Xue Yu: he [the author] agrees that we should speak Standard English right but he also agrees that certain situations or events okay you can codeswitch meaning that you use Singlish or mother tongue. How many of you don't get this right? Please put up your hand.

The observation notes of one of the researchers in the class summarizes what Xue $\mathrm{Yu}$ wants to tell her students about codeswitching in society: "Tr [Teacher] introduces 
codeswitching and says that sometimes we may have to use MT or Singlish although most of the time we are expected to speak standard English."

Second, Xue Yu provides 'expert' explanation to Singlish as a legitimate form of English language use while inserting some crucial points about Singlish which correct common misconceptions:

Xue Yu: ... when we started speaking English and making it our first language you know a lot of people learn something new and then we already had or mother tongue Malay, Tamil. It's a natural process somehow you use remember I did mention before, it doesn't mean you use Singlish words you are stupid. Remember because English is different from other languages right? Like the Chinese structure we use English words [based] on Chinese sentence structure, that's what we call literal translation.

Recall above Xue Yu's avoidance of addressing directly a student's question about whether one can use a particular Singlish sentence or not. In reminding students about the structural systematicity of Singlish, Xue Yu helps students see it as a legitimate form of communication without necessarily openly endorsing its use.

Third, Xue Yu digs deeper into the organizational structure of the essay, explaining to students how ideas are linked together by cohesive devices such as 'however' or 'but', and in the process of doing so she puts forward arguments about Standard English and Singlish without necessarily explicitly claiming those ideas are hers. She points to paragraphs which argue that the use of Singlish (and other 'mother tongue' languages, for that matter) is justified, and then also discuss paragraphs which argue for the need for Standard English because certain social contexts call for it: 
Xue Yu: Alright so it says here although we should speak in Standard English there are some situations. Look at the word 'although', that means this word although signals to the reader that you are going to discuss two aspects of your point of view. Right? So the two aspects will be agree and not agree right okay? So it's not only one because you use the word 'although'. Remember our discussion 'although' is to show contrast that means there are two ideas in that sentence so the first idea is we should speak Singlish. The second idea is there are some situations which we can use singlish or mother tongue. Right? So if you wanna use 'however' then, we should stick to English 'however' right or 'but', there are some situations which require us.

In enumerating the pros and cons of using Singlish and Standard English, Xue Yu provides students with a wider discourse upon which students can talk about English linguistic diversity in the classroom. Yet she does this without telling students explicitly that it is fine to use Singlish in the classroom. Here - as well as with her brief explanation on codeswitching and why it is 'natural' for speakers to switch between different Englishes, as well as with her assertion about the structural systematicity of Singlish - we see how Xue Yu provides students with a wider range of stances concerning the use of a non-standard form and/or variety of English. These seemingly simple but subtle ways to negotiate different ideologies and practices of Unequal Englishes in the classroom help nurture dispositions among students which embrace, rather than devalue, the use of Singlish.

\section{Conclusion}


It is true that some educational and socio-political regimes are more tightly-controlled than others, and Singapore is one of those which scholars of various theoretical and political orientations agree to be an exemplar of a highly centralized educational system which is institutionally and ideologically linked with the politics and vision of the government (Chua 2009; Wee 2018; Tan and Dimmock 2014). However, while the "linguistic lives of Singaporeans may appear tightly disciplined" (Kramer-Dahl 2003, 163), "people have ways of escaping the ideological formations of the government." Educational and language policies in Singapore have most often clearly reflected the agenda of the government, and the implementation of such policies have likewise also been strongly pushed by the state in a largely top-down fashion. Nevertheless, the classroom, as we have also seen in the sample data above examining and tracking Xue Yu's stances and practices in relation to fostering translingual dispositions, reproduces yet also opens up spaces for change for teachers and students. Given Singapore's historical embeddedness in colonially-induced ideologies and practices, coupled with the country's resolute and singular drive towards global competitiveness and the state's control of the educational system, it is understandable that teachers (and students for that matter) decide to work within the confines of institutionallymandated practices and frameworks. Singapore's Out-of-bounds (OB) markers (or those areas which the government has defined to be politically sensitive and should not be ventured into), do continue to shape people's everyday politics (Hudd 2018: Han 2018), and this is the same with teachers who are deeply aware of such markers and the implications of "stepping beyond the bounds of state-sanctioned behaviour" (Han 2018, 85; see Baildon and Sim 2009; Baidon et al. 2018).

Thus, it is in this context of pedagogical practice where we appreciate Xue Yu's struggles to deal with Unequal Englishes in the classroom. While she seems unwilling (or not ready) to explicitly endorse the use of Singlish in the classroom, she nevertheless has subtly 
opened up a space for Singlish in the classroom through subtle strategies in her lessons. She is conflicted in terms of her stance towards allowing the use of Singlish in the classroom, but she is clear in terms of its pedagogical uses and its legitimacy as a systemically logical form of communication. Amidst her conflicted practice and ideologies in the classroom, she persists in opening up Singlish to her students because of its pedagogical use and its identityaffirming role in and outside the classroom.

All is not completely well in the classroom with the kinds of practices and thinking espoused by $\mathrm{Xue} \mathrm{Yu}$ - but this is exactly the point. Fostering translingual dispositions occurs under conditions of ideological and institutional surveillance, and this must be acknowledged and incorporated into any framework of ideas which aim to identify or deploy strategies to be used in the classroom to make teaching and learning more effective and, more importantly, just and equitable. However, the possibilities exist and available for transforming the classroom, steeped in systemic inequalities embedded in linguistic injustice such as what is realized through the mechanisms and ideologies of Unequal Englishes. These possibilities could thus be exploited in teacher education where teachers are provided critical and muchneeded training in multilingual pedagogies such as the incorporation of ideas concerning translingualism and World Englishes. It is important, however, to acknowledge that limits of initiating changes though the accommodation of alternative methods of teaching and learning through non-standard languages and language varieties. What could be done is also to sensitize teachers into teacher ideology or an approach to teacher training which focuses on helping teachers examine their own language belief systems and how their beliefs about English facilitate or impede the provision of linguistic justice. To quote Trueba and Bartolomé (2000), "the need for clarity of political beliefs, practices, and commitments is as important as the actual pedagogical strategies used in instruction" (p. 278). 
While it is likely (and expected) that teachers like Xue Yu will continue to tow the ideological line of the state and the institutions that represent it, the dominant presence of Standard English could still be interrogated. Such is the case of Xue Yu's secondary 4 students. In a post-observation interview, she narrates how she continues to urge them to use Standard English so they will not make the mistake of using Singlish in their writing assignments, but is pushed back by her students: "Cher, can you not be formal all the time?" to which she concedes by "trying to use informal but within Standard English."

\section{References}

Arnaut, K., J. Blommaert, B. Rampton, and M. Spotti (Eds.). 2015. Language and Superdiversity. New York and London: Routledge.

Baildon, M., S. Afandi, S. Bott, and C. Rajah. 2018. "Guiding Students in Singapore to Investigate Historical Controversy Using a Disciplinary Approach.” History Education Research Journal, 15(2), 308-327.

Baildon, M., and J. B-Y Sim. 2009. 'Notions of Criticality: Singaporean Teachers' Perspectives of Critical Thinking in Social Studies. Cambridge Journal of Education, 39(4): 407-422.

Barbour, C., and K. L. Quinn. 2020. Los Pájaros are Feliz and are Dreaming about Gwiazdy: Facilitating Translingual Creative Writing in the Primary Classroom. English in Education. doi: 10.1080/04250494.2019.1703553.

Bhatt, R. M. 2001. "World Englishes.” Annual Review of Anthropology 30(1): 527-550.

Bolton, K. 2019. “Braj B. Kachru and Asian Englishes.” World Englishes, 38(1-2): 67-77.

Bolton, K., and Ng, B. C. 2014. The Dynamics of Multilingualism in Contemporary Singapore. World Englishes 33(3): 307-318. 
Bourdieu, P. 1977. "The Economics of Linguistic Exchanges.” Information (International Social Science Council) 16(6): 645-668.

Byram, M. 1997. Teaching and Assessing Intercultural Communicative Competence.

Clevedon: Multilingual Matters.

Canagarajah, A. S. 2006. "The Place of World Englishes in Composition: Pluralization Continued." College Composition and Communication 57(4): 586-619.

Chakravarti, P. 2008. Decolonising and Globalising English Studies: The Case of English Textbooks in West-Bengal India. English in Education 42(1): 37-52.

Chua, B. H. 2009. "Being Chinese under Official Multiculturalism in Singapore.” Asian Ethnicity 10(3): 239-250.

Chua, C. S. K. 2015. Singlish Strikes Back in Singapore. In Unequal Englishes: The Politics of Englishes Today, edited by R. Tupas, 185-200. London: Palgrave Macmillan. Data.gov.sg 2018. "Singapore Residents by Age Group, Ethnic Group and Gender.” Accessed 19 September 2019. https://data.gov.sg/dataset/resident-population-byethnicity-gender-and-age-group?view_id=8ff89d3f-48c8-46e4-8a4da8b9f152976f\&resource_id=f9dbfc75-a2dc-42af-9f50-425e4107ae84.

Dovchin, S., S. Sultana, and A. Pennycook. 2016. Unequal Translingual Englishes in the Asian Peripheries. Asian Englishes 18(2): 92-108.

Farrell, T. S., and S. T. K. Kun. 2007. "Language Policy, Language Teachers' Beliefs, and Classroom Practices." Applied Linguistics 29(3): 381-403.

Fong, V., L. Lim, and L. Wee. 2002. “"Singlish': Used and abused.” Asian Englishes 5(1): $18-39$.

García, O., and A. M. Lin. 2017. “Translanguaging in Bilingual Education. In Bilingual and Multilingual Education. Encyclopedia of Language and Education (3rd ed.), edited by O. García O., A. Lin A., S. May, 117-130. Cham: Springer. 
García, O., and R. Otheguy. 2019. Plurilingualism and Translanguaging: Commonalities and Divergencies. doi: https://doi.org/10.1080/13670050.2019.1598932

Goddard, A., A. Henry, M. Mondor, and M. Laaken. 2013. “'Have You Ever Been to England? You Know, They Speak Really Wweird English There': Some Implications of the Growth of English as a Global Language for the Teaching of English in the UK." English in Education 47(1): 79-95.

Godley, A. J., J. Sweetland, R. S. Wheeler, A. Minnici, and B. D. Carpenter. 2006. “Preparing Teachers for Dialectally Diverse Classrooms.” Educational Researcher 35(8): 30-37.

Han, K. 2018. “Keep Calm and Carry On: How Singapore’s Leaders Use the Gospel of Business to Stifle Dissent.” World Policy Institute 1(25): 84- 90.

Hiramoto, M. 2019. “Colloquial Singapore English in Advertisements.” World Englishes 38(3): 450-462.

Holliday, A. (2006). Native-speakerism. ELT Journal, 60(4): 385-387.

Hudd, S. 2018. "Free Amos? Overstepping the Boundaries of Team Singapore." Journal of Applied Youth Studies 2(3): 3-17.

Jarvis, M., and K. Bokor. 2011. “Connecting with the 'Other' in Technical Communication: World Englishes and Ethos Transformation of US Native English-Speaking Students. Technical Communication Quarterly 20(2): 208-237.

Kachru, B. B. 1996. "World Englishes: Agony and Ecstasy.” Journal of Aesthetic Education 30(2): 135-155.

Kachru, B. B. 1988. “The Sacred Cows of English.” English Today 4(4): 3-8.

Kachru, B. B. 1986. “The Power and Politics of English.” World Englishes 5(2-3): 121-140.

Kimball, E. 2015. “Translingual Communities: Teaching and Learning Where You Don't Know the Language.” Community Literacy Journal 9(2): 68-82. 
Koh, A. 2004. "Singapore Education in 'New Times': Global/local imperatives." Discourse: Studies in the Cultural Politics of Education 25(3): 335-349.

Kramer-Dahl, A. 2003. “Reading the 'Singlish Debate': Construction of a Crisis of Language Standards and Language Teaching in Singapore." Journal of Language, Identity, and Education 2(3): 159-190.

Kubota, R. 2001. "Teaching World Englishes to Native Speakers of English in the USA." World Englishes 20(1): 47-64.

Kwek, M. Y. P., and L. Alsagoff. 2006. "English Teachers Using Singapore Colloquial English in the Classroom: An Examination of Two Secondary School Teachers' Lessons.” Paper Read During the ERAS Conference, Singapore, 29-31 May 2006, organised by Educational Research Association of Singapore (ERAS).

Lee, E., and S. Canagarajah. 2019. "The Connection Between Transcultural Dispositions and Translingual Practices in Academic Writing.” Journal of Multicultural Discourses 14(1): $14-28$.

Lee, J. W., and C. Jenks. 2016. "Doing Translingual Dispositions. College Composition and Communication 68(2): 317-344.

Lee, S. K., C. B. Goh, B. Fredriksen, and J. P. Tan (Eds.). 2008. Toward a Better Future: Education and Training for Economic Development in Singapore Since 1965. Washington D.C. and Singapore: The World Bank and National Institute of Education.

Li, P. 2015. "Glocalization and the Spread of Unequal Englishes: Vernacular Signs in the Center of Beijing." In Unequal Englishes: The Politics of Englishes Today, edited by R. Tupas, 163-184. London: Palgrave Macmillan.

Li, W. 2018. "Translanguaging as a Practical Theory of Language.” Applied Linguistics 39(1): 9-30. 
Li, W. 2016. "New Chinglish and the Post-Multilingualism Challenge: Translanguaging ELF in China." Journal of English as a Lingua Franca 5(1): 1-25.

Lim, L. 2015. “Coming of Age, Coming Full Circle: The (Re)positioning of (Singapore) English and Multilingualism in Singapore at 50.” Asian Englishes 17(3): 261-270. MacSwan, J. 2019. “A Multilingual Perspective on Translanguaging. In Decolonizing Foreign Language Education: The Mis-teaching of English and Other Colonial Languages, edited by D. Macedo, 186-219. New York: Routledge.

Matsuda, A. 2003. "Incorporating World Englishes in Teaching English as an International Language.” TESOL Quarterly 37(4): 719-729.

Matsuda, A. 2002. “'International Understanding' Through Teaching World Englishes.” World Englishes 21(3): 436-40.

Mesthrie, R. 2019. “Indian English in Theory and Action.” World Englishes 38(1-2): 155161.

Pakir, A. 1991. "The Range and Depth of English-knowing Bilinguals in Singapore. World Englishes 10(2): 167-179.

Park, J. S-Y (2011). “The Promise of English: Linguistic Capital and the Neoliberal Worker in the South Korean Job Market." International Journal of Bilingual Education and Bilingualism 14(4): 443-455.

Parkin, D. 2015. “From Multilingual Classification to Translingual Ontology: A Turning Point.” In Language and superdiversity, edited by K. Arnaut, K., J. Blommaert, B. Rampton, 81-98. New York and London: Routledge.

Pennycook, A. 2019. “From Translanguaging to Translingual Activism.” In Decolonizing Foreign Language Education: The Mis-teaching of English and Other Colonial Languages, edited by D. Macedo, 169-185. New York: Routledge.

Pennycook, A. 2017. The Cultural Politics of English as an International Language (first 
published in 1994). London and New York: Routledge.

Pennycook, A. 2006. "Language Education as Translingual Activism.” Asia Pacific Journal of Education 26(1): 111-114.

Platt, J. T., Weber, H., and Ho, M. L. 1984. The New Englishes. London: Routledge and Kegan Paul.

PuruShotam, N. S. 2011. Negotiating Language, Constructing Race: Disciplining Difference in Singapore (Vol. 79). Berlin |and New York: Walter de Gruyter.

Reagan, T. (2016). "The Conceptualization of Language Legitimacy. Critical Inquiry in Language Studies 13(1): 1-19.

Rubdy, R. 2001. “Creative Destruction: Singapore's Speak Good English Movement.” World Englishes 20(3): 341-355.

Sabaté-Dalmau, M. 2018. “'I Speak Small’: Unequal Englishes and Transnational |Identities among Ghanaian Migrants.” International Journal of Multilingualism 15(4): 365-382.

Saraceni, M. 2015. World Englishes: A Critical Analysis. London: Bloomsbury Publishing.

Sadeghpour, M., and Sharifian, F. 2019. "World Englishes in English Language Teaching." World Englishes 38(1-2): 245-258.

Smith, L. E. (Ed.). 1987. Discourse Across Cultures: Strategies in World Englishes. London: Prentice-Hall.

Tan, C. Y., and Dimmock, C. 2014. "How a 'Top-performing 'Asian School System Formulates and Implements Policy: The Case of Singapore." Educational Management Administration \& Leadership 42(5): 743-763.

Tan, Y. Y. 2014. "English as a 'Mother Tongue' in Singapore.” World Englishes 33(3): 319339.

Trueba, E.. and Bartolomé, L. (2000). "Beyond the Politics of Schools and the Rhetoric of 
Fashionable Pedagogies: The Significance of Teacher Ideology.” In Immigrant Voices: In Search of Educational Equity, edited by E. Trueba \& L. Bartolomé, 277292. Lanham, MD: Rowman \& Littlefield.

Tupas, R. (2018). “Singlish in the Classroom: Is Singapore Ready for Additive Bidialectalism?” International Journal of Bilingual Education and Bilingualism 21(8): 982-993.

Tupas, R. (2015). Unequal Englishes: The Politics of Englishes Today. London: Palgrave Macmillan.

Tupas, R. (2011). “English-knowing Bilingualism in Singapore: Economic Pragmatism, Ethnic Relations and Class." In English Language Education Across Greater China, edited by A. Feng 46-69. Bristol: Multilingual Matters.

Vaish, V. 2012. “Teacher Beliefs Regarding Bilingualism in an English Medium Reading Program. International Journal of Bilingual Education and Bilingualism 15(1): 53-69.

Vaish, V., and Subhan, A. 2015. "Translanguaging in a Reading Class.” International Journal of Multilingualism 12(3): 338-357.

Velasco, Y. P. 2019. "The Kachruvian Connection and English Language Teaching in the Philippines." World Englishes 38(1-2): 294-302.

Vertovec, S. 2007. "Super-diversity and its Implications.” Ethnic and Racial Studies 30(6): 1024-1054.

Wee, L. 2018. The Singlish Controversy: Language, Culture and Identity in a Globalizing World. Cambridge: Cambridge University Press.

Wee, L. 2014a. "Linguistic Chutzpah and the Speak Good Singlish Movement. World Englishes 33(1): 85-99.

Wee, L. 2014b. "The Minoritization of Languages in Singapore. In Language, Education and 
Nation-building, edited by P. Sercombe and R. Tupas, 181-199. London: Palgrave Macmillan.

Wee, L. 2002. "When English is Not a Mother Tongue: Linguistic Ownership and the Eurasian Community in Singapore. Journal of Multilingual and Multicultural Development 23(4): 282-295.

Wheeler, R. 2006. "What Do We Do about Student Grammar - All Those Missing -ed's and s's? Using Comparison and Contrast to Teach Standard English in Dialectally Diverse Classrooms.” English Teaching 5(1): 16-33. 